\title{
Board of Director Characteristics, Institutional Ownership, and Accounting Conservatism
}

\author{
NI WAYAN RUSTIARINI* \\ AGUS WAHYUDI SALASA GAMA \\ Universitas Mahasaraswati Denpasar \\ DESAK NYOMAN SRI WERASTUTI \\ Universitas Pendidikan Ganesha
}

\begin{abstract}
One of the determinants of conservatism is Board of Directors (BoD) characteristics. Several studies have examined the relationship between board characteristics and accounting conservatism. Nonetheless, previous empirical findings show heterogeneous and inconclusive results. This study aims to prove the role of board characteristics, namely board female, board expertise, board overconfidence, and board size in accounting conservatism. This study also examines institutional ownership as moderating variable. This research was conducted on 118 manufacturing companies for three periods, namely 2017-2019. The data analysis technique used is Partial Least Square. The test results prove that board female and board expertise increase accounting conservatism, while board overconfidence reduces conservatism. However, there is no relationship between board size and accounting conservatism. This study also indicates that institutional ownership strengthens the relationship between board females and board expertise to accounting conservatism. Contrary, institutional ownership fails as moderating variable between board size and accounting conservatism relationship. In testing the board overconfidence variable, the percentage of institutional ownership variable cannot be a moderating variable. Nevertheless, the interaction between board overconfidence and the number of institutional investors has a negative effect on accounting conservatism.
\end{abstract}

Keywords: Accounting Conservatism, Board of Directors, Institutional Ownership

Abstrak: Salah satu faktor penentu praktik konservatisme adalah karakteristik dewan direksi. Sejumlah penelitian telah menguji hubungan karakteristik dewan direksi dan konservatisme akuntansi. Meskipun demikian, temuan empiris sebelumnya menunjukkan hasil yang heterogen dan tidak meyakinkan. Penelitian ini bertujuan untuk membuktikan peran karakteristik dewan direksi, yaitu direksi perempuan, keahlian direksi, sikap overconfidence direksi, dan ukuran direksi terhadap konservatisme akuntansi. Studi ini juga menguji peran kepemilikan institusional sebagai variabel moderasi. Penelitian ini dilakukan pada 118 perusahaan manufaktur untuk tiga periode amatan, yaitu tahun 2017-2019. Teknik analisis data yang digunakan adalah Partial Least Square. Hasil pengujian membuktikan bahwa direksi perempuan dan keahlian direksi meningkatkan konservatisme akuntansi sedangkan

* Corresponding author: rusti_arini@ unmas.ac.id 
board overconfidence menurunkan konservatisme. Meskipun demikian, tidak ada hubungan antara ukuran direksi dan konservatisme akuntansi. Studi ini juga mengindikasikan bahwa kepemilikan institusional memperkuat hubungan direksi perempuan dan keahlian direksi terhadap konservatisme akuntansi. Sebaliknya, kepemilikan institusional gagal sebagai variabel moderasi dalam hubungan ukuran direksi dan konservatisme akuntansi. Dalam pengujian variabel sikap overconfidence direksi, persentase kepemilikan institusional tidak berperan sebagai variabel moderasi. Namun, interaksi antara sikap overconfidence direksi dan jumlah investor institusional berpengaruh negatif terhadap konservatisme akuntansi.

Kata Kunci: Konservatisme Akuntansi, Dewan Rireksi, Kepemilikan Institusional

\section{Introduction}

Accounting conservatism is one of the elements that affect the quality of financial statements. Companies that apply conservatism principles tend to verify good news as an advantage rather than admit bad news as a loss (Basu, 1997). However, the applying of the conservatism principle is determined by BoD's characteristics (Francis et al., 2015; Nasr \& Ntim, 2018). Several studies have examined the relationship between $\mathrm{BoD}$ characteristics and accounting conservatism. Nevertheless, previous empirical findings show heterogeneous and inconclusive results (Enache \& García-Meca, 2019). Therefore, this study examines four characteristics of $\mathrm{BoD}$, namely board female, board expertise, board overconfidence, and board size in accounting conservatism.

This research has three research motivations. First, conservatism is one of the fundamental characteristics of financial reporting (Ball, 2001; Krishnan \& Visvanathan, 2008). Conservatism has also become the most influential valuation principle in accounting practice for 500 years old (Basu, 1997). However, currently, there are many financial restatements and accounting fraud scandals within the company. This phenomenon emphasizes the importance of conservative financial reporting practices (Song et al., 2016). Therefore, this study explores the practice of conservatism in manufacturing companies.

Second, the BoD is a corporate organ that applies the principles of accounting conservatism in financial reporting. The characteristics of the BoD determine the quality of the financial statements (García-Sánchez et al., 2017). Nevertheless, there is still 
debate about the relationship between the BoD and accounting conservatism. For example, research results on the existence of female executives are still limited and have mixed results (Francis et al., 2015; Ho et al., 2015). Besides, there are two conflicting views on the role of board size in conservatism. The first view assumes that large board sizes increase conservatism (Farizal et al., 2017; Muttakin et al., 2019). However, another view states that a large board reduces accounting conservatism (Abdul-Manaf et al., 2014; Boussaid et al., 2015; Nasr \& Ntim, 2018). Research that examines board expertise and accounting conservatism is scarce. Previous research has mainly examined the relationship between audit committee expertise and conservatism (Hamdan, 2020; Kao \& Chu, 2016; Marzuki et al., 2016; Sultana, 2015). Therefore, this study examines the influence of $\mathrm{BoD}$ characteristics on accounting conservatism.

Third, this study uses two indicators of institutional ownership measurement, namely the percentage of share ownership and the number of institutional investors that hold common stock. The majority of studies use the percentage of share. However, this indicator does not capture variation in the number of institutional investors that contribute to the percentage of shares (Cassell et al., 2017). Besides, there are conflicting empirical findings. On the one hand, high institutional ownership requires companies to be more conservative (Alkurdi, Al-Nimer, \& Dabaghia, 2017; El-habashy, 2019; Lin, Wu, Fang, \& Wun, 2014; Majeed, Xian-zhi Zhang, \& Wang, 2017; Ramalingegowda \& Yu, 2012; Song, 2015). On the other hand, institutional ownership potentially reduces conservatism (Ahmed \& Duellman, 2007; Chi et al., 2009; Lin, 2016). Other studies have revealed that institutional ownership does not affect accounting conservatism (Ahmed \& Henry, 2012). Therefore, this study adds institutional ownership as a moderating variable in the relationship between the BoD characteristics and accounting conservatism.

This study aims to prove the role of BoD characteristics, namely board female, board expertise, board overconfidence, and board size, on accounting conservatism. Also, this study explores the moderating effect of institutional ownership in the board characteristic and accounting conservatism relationship. The result shows that board female and board expertise increase conservatism, while board overconfidence reduces 
accounting conservatism. However, there is no relationship between board size and accounting conservatism. This study also indicates that institutional ownership strengthens the relationship between board females and board expertise to accounting conservatism. Contrary, institutional ownerships do not moderate the relationship between board size and accounting conservatism. In testing the board overconfidence variable, the percentage of institutional ownership variable cannot serve as moderating factor. Nevertheless, the interaction between board overconfidence and the number of institutional investors has a negative effect on accounting conservatism.

The results provide theoretical and practical contributions. Theoretically, the results confirm the Agency Theory that institutional ownership is an effective external monitoring mechanism to strengthen the relationship between board characteristics and accounting conservatism. Practically, these empirical findings provide insights for practitioners and regulators to consider directors' characteristics, such as gender and overconfidence in making financial decisions and presenting quality financial reports.

\section{Theoretical Framework and Hypothesis Development}

\subsection{Agency Theory}

Agency theory discusses the existence of an agency relationship between shareholders and company management (Jensen \& Meckling, 1976). In an agency contract, actions are taken by the board of directors on behalf of the shareholders. Managers also have access to more information about management activities and company operations, while shareholders only get information through management's financial reports. In this case, an appropriate control mechanism is needed to oversee the BoD's actions by emphasizing the importance of applying accounting conservatism. Conservatism plays an essential role in offsetting information bias between management and shareholders (Watts, 2003). The accounting literature notes that conservative financial reporting reduces agency problems, information asymmetry and reduces litigation costs (Affes \& Sardouk, 2016; Francis et al., 2013; Watts, 2003).

In the accounting conservatism context, institutional ownership is the crucial element to improve conservative financial statements. Institutional investors have large 
shares to monitoring the process of the financial statements. Besides, institutional investors focus on the long-term benefits of investing, and they tend to have higher demands to increase accounting conservatism (Majeed et al., 2017). The practice of accounting conservatism protects the funds invested by shareholders in the company (Cullinan et al., 2012) and reduces the opportunities for managers to manipulate financial reporting (Ahmed \& Duellman, 2007; El-habashy, 2019). Thus, institutional ownership is considered capable of improving financial report quality (Song, 2015).

\subsection{Board Female and Accounting Conservatism}

In recent years, the number of women in executive positions has increased significantly. The existence of women in top positions is not only a competitive advantage (Stephenson \& Nt, 2004; Widhiastuti et al., 2020) but influences the company's financial decisions. Financial decision-making between female and male directors is very different (Huang \& Kisgen, 2013). Based on accounting literature, female executives are more conservative (Boussaid et al., 2015; Francis et al., 2013, 2015; Ho et al., 2015; Krishnan \& Parsons, 2008; Peni \& Vähämaa, 2010). They tend to make conservative or low-risk decisions (Vermeir \& Van Kenhove, 2008). These findings support the psychology, socialization, and economic literature that women generally tend to avoid risks (Francis et al., 2015). The decisions made by female executive boards are very different from those of male executive boards (Huang \& Kisgen, 2013; Levi et al., 2008). These differences in character motivated researchers to begin investigating the role of female executives in financial decision-making.

In terms of financial decisions, women tend to avoid making less risky investment decisions (Francis et al., 2015). For example, female chief financial officers do not more acquisition activity (Francis et al., 2015), reduce leverage or debt issuance (Huang \& Kis gen, 2013), and reduce the corporate litigation risk (Francis et al., 2015). As a result, the company's growth is slower than companies controlled by male chief financial officers (Francis et al., 2015). Concerning the implementation of duties in accounting, female executive boards have a more conservative attitude. This character keeps women from engaging in unethical accounting practices, such as earnings management (Ho et 
al., 2015) or tax aggressiveness (Francis et al., 2015). Therefore, companies led by top female leaders are considered to have higher earnings quality (Francis et al., 2015; Krishnan \& Parsons, 2008; Labelle et al., 2010). The existence of gender diversity increases financial reporting transparency (Francis et al., 2015; Gul et al., 2011). Thus, the hypothesis is formulated as follows:

\section{H1: Board female has a positive effect on accounting conservatism.}

\subsection{Board Expertise and Accounting Conservatism}

One of the characteristics of the BoD that plays a role in the preparation of conservative financial statements is accounting or finance expertise. Directors with accounting expertise can oversee financial reporting, increase transparency, and reduce litigation risk (García-Sánchez et al., 2017). Moreover, the regulator emphasized the importance of directors having accounting or financial expertise to improve the company's reported earnings quality. Financial expertise allows directors to analyze information related to the company's operational activities and financial condition (Wang et al., 2015).

In the context of financial reporting, the directors with accounting expertise make a significant contribution to financial decision-making, such as operational, investment, and dividend policies (Dill, 2013). Based on their capacity and expertise, the BoD substantially supervises preparing financial statements. $\mathrm{BoD}$ has the authority to determine performance targets, reported figures, and the timing of report submissions (Basu \& Liang, 2019; Enache \& García-Meca, 2019). In addition, the BoD with financial expertise can apply appropriate accounting standards, including accounting conservatism. Therefore, directors with accounting or financial expertise positively impact financial reporting quality, including the preparation of conservative financial statements (García-Sánchez et al., 2017). Thus, the hypothesis is formulated as follows: H2: Board expertise has a positive effect on accounting conservatism.

\subsection{Board Overconfidence and Accounting Conservatism}

In the financial sector, the concept of "overconfidence" was first put forward by Roll (1986). This term is interpreted as managerial arrogance in decision-making. 
Managers are overly confident usually over-acknowledge company earnings (Malmendier \& Tate, 2015). Overconfidence top management is also optimistic in determining the value of its assets or equity, thereby reducing conservatism (Ahmed \& Duellman, 2013; Heaton, 2002). In terms of project appraisal or company equity, managers who overconfidence perceive a negative net present value as a positive net present value, causing mistakes in making business decisions (Heaton, 2002). On the other hand, companies also underestimate the impact of adverse events (negative) on the company's cash flow (Malmendier \& Tate, 2015). Therefore, overconfidence distorts the company's financing decisions, investment, and accounting policies (Graham et al., 2005; Malmendier \& Tate, 2015).

In the accounting context, one of the top executive behaviors that create difficulties in accounting reporting practice is board overconfidence (Chouaibi \& Chiekh, 2017). Overconfidence is associated with management's earnings figures (Hilary \& Hsu, 2011; Libby \& Rennekamp, 2012). Previous empirical findings reveal that overconfidence manage ment is positively related to the possibility of financial reporting fraud (Chouaibi \& Chiekh, 2017; Schrand \& Zechman, 2012). This phenomenon is caused by two conditions, namely 1) management accelerates the recognition of earnings or profits, and 2) management underestimating the value of the liability/loss or even delaying the recognition of the loss. Both of these actions lead to aggressive financial reporting (Ahmed \& Duellman, 2013). Using three different conservatism indicators, Ahmed and Duellman (2013) revealed that overconfidence negatively influences accounting conservatism. Other studies also state a negative relationship between overconfidence and accounting conservatism (Ahmed \& Duellman, 2013; Chouaibi \& Chiekh, 2017; Hwang et al., 2015). Thus, the hypothesis is formulated as follows:

H3: Board overconfidence has a negative effect on accounting conservatism.

\subsection{Board Size and Accounting Conservatism}

Agency theory explains that the board size is expected to minimize agency conflicts through conservative accounting principles. There are two competing views regarding the board size's role in accounting conservatism (Ahmed \& Duellman, 2007). The first, 
boards' large size allows the board to have various specializations (expertise) related to the quality of financial reports (Ebrahim \& Fattah, 2015). Research by Ahmed and Henry (2012) shows that large board sizes lead to inaccuracies in earnings and book values. Thus, the large board increases conservatism (Farizal et al., 2017; Muttakin et al., 2019). Second, a large board is less effective than a small board. Large membership makes it difficult for members to coordinate and communicate. It leads to disputes and interdependence among board members (Ahmed \& Duellman, 2007; Eisenberg et al., 1998). Therefore, a large board reduces accounting conservatism level (Abdul-Manaf et al., 2014; Boussaid et al., 2015; Nasr \& Ntim, 2018)

Although there are two different views, this study assumes that a large board increase accounting conservatism. Many board members will increase effectiveness and performance, mainly in building networks and accessing economic resources (Almutairi \& Quttainah, 2019; Kiel \& Nicholson, 2003). Although many board members lead to significant agency costs, the benefits obtained are more significant than those incurred (Coles et al., 2008). Previous studies revealed that prominent board members would reduce the risk potential and company bankruptcy (Anderson et al., 2004; Darrat et al., 2014; Platt \& Platt, 2012). In the conservatism context, empirical findings found that board size positively affects conservative accounting practices (Farizal et al., 2017; Muttakin et al., 2019). Thus, the first hypothesis is formulated as follows:

H4: Board size has a positive effect on accounting conservatism.

\subsection{Board Female, Institutional Ownership, and Accounting Conservatism}

Companies with high institutional ownership tend to have an effective and adequate external supervision system (Lin et al., 2014), and it has the potential to increase conservatism practices. Also, institutional shareholders generally have higher skills to reduce opportunistic management behavior and earnings management potential (Farooq \& El Jai, 2012). This characteristic is in line with the mindset of women that tend to be conservative. Female executives are more sensitive to the risks that the company must bear. They tend to avoid the potential for overstatement or aggressive accounting reporting (Francis et al., 2015). This conservative thinking causes the female 
board of directors to reject fraudulent behavior firmly (Rustiarini \& Merawati, 2021). Thus, institutional investors will strengthen the decision of board females to applying conservative accounting principles. Thus, the hypotheses are formulated:

H5: Institutional ownership strengthens the relationship between female boards and accounting conservatism.

\subsection{Board Expertise, Institutional Ownership, and Accounting Conservatism}

The rife accounting scandals encourage the company to increase corporate governance capacity, such as external monitoring. One element of governance that can perform an external monitoring role effectively is institutional ownership. Institutional investors are generally the majority shareholders because they have significant share ownership in the company. The existence of extensive holdings motivates institutional investors to perform an influential supervisory role. Institutional investors continuously monitor and provide advice to improve the quality of financial reports. Meanwhile, directors with accounting (finance) expertise can serve the interests of shareholders (Güner et al., 2008). Thus, the hypotheses are formulated:

H6: Institutional ownership strengthens the relationship between board expertise and accounting conservatism.

\subsection{Board Overconfidence, Institutional Ownership, and Accounting Conservatism}

This hypothesis examines institutional ownership's role as moderating between board overconfidence and accounting conservatism. Institutional investors primarily focus on the long-term benefits of investing in having higher demands to increase accounting conservatism (Majeed et al., 2017). Intense external monitoring is seen as reducing the impact of the board overconfidence behavior. The previous findings state that a board overconfident tends to reduce conservatism's financial statements (Chouaibi \& Chiekh, 2017; Hwang et al., 2015; Ramsheh \& Molanzari, 2014). The overconfidence attitude causes the CEO to delay acknowledging losses, but he optimistic about revenue recognition (Chouaibi \& Chiekh, 2017). This condition indeed endangers the company's financial position in the future. In such a situation, institutional shareholders control managerial behavior by cutting compensation, eliminating bonuses, and firing managers (Cullinan et al., 2012). Therefore, high external monitoring power is considered to 
reduce the negative impact of manager overconfidence on accounting conservatism practices. Thus, the hypothesis is formulated as follows:

H7: Institutional ownership weakens the relationship between board overconfidence and accounting conservatism.

\subsection{Board Size, Institutional Ownership, and Accounting Conservatism}

Institutional shareholders play an essential role in the external monitoring mechanism (El-habashy, 2019). Institutional ownership is effective monitoring to reducing opportunistic management behavior (Firth et al., 2016). Institutional investors have a large number of shares. They have voting rights to refuse financial decisions that tend to benefit management (Cullinan et al., 2012). The high share ownership motivates institutional investors to dedicate themselves to actively involved in corporate governance (Lin et al., 2014). This condition allows institutional investors to pressure management to apply accounting conservatism. Therefore, published financial statements reflect a high level of accounting conservatism. Thus, the hypothesis is formulated as follows:

H8: Institutional ownership strengthens the relationship between board size and accounting conservatism.

\section{Research Method}

\subsection{Population and Sample}

The research population is all manufacturing companies listed on the Indonesia Stock Exchange in 2017-2019. Determination of the sample using purposive sampling method with criteria, namely 1) manufacturing companies listed for three periods; 2) the company publishes an annual report during the observation period; 3) the company has the data needed in this study. Based on these criteria, there are 118 companies sampled. There were 354 data for the three years of observation. This study uses secondary data from the company's annual report.

\subsection{Operational Definition of Variables}

This study's dependent variable is accounting conservatism. The independent variable is the $\mathrm{BoD}$ characteristic consists of four variables: board female, board 
expertise, board overconfidence, and board size. This study uses institutional ownership as a moderating variable. This study also uses seven variables to control the research model: profitability, leverage, firm size, market to book value, litigation risk, sales growth, and operating uncertainty. Profitability is a control variable because high profitability companies tend to be more conservative in preparing financial reports (Hendro \& Wardhani, 2015). The companies with high leverage also tend to apply the principle of conservatism to reduce contract costs and agency conflicts (Ahmed, Billings, Morton, \& Stanford-Harris, 2002). This study also controls firm size because larger firms have lower asymmetric earnings timeliness (Givoly et al., 2007). The Market to Book (MTB) variable is also related to the company's efforts to take advantage of investment opportunities (Roychowdhury \& Watts, 2007). Companies also encounter a high risk of litigation to apply accounting conservatism to reduce this risk (Chung et al., 2013; Watts, 2003). Meanwhile, this study also uses sales growth because it increases the accrual value of accounts such as receivables (Ahmed \& Duellman, 2007). Finally, this study controls operating uncertainty because this variable can increase conflicts of interest between stakeholders. Thus, companies should prepare more conservative financial statements (Ahmed \& Duellman, 2013). The explanation of the operational definition of each variable is presented in Table 1.

Table 1

Definition of Operational Variables

\begin{tabular}{|c|c|c|}
\hline No & Variable & Indicator \\
\hline 1 & $\begin{array}{l}\text { Accounting } \\
\text { conservatism }\end{array}$ & $\begin{array}{l}\text { The measurement of accounting conservatism using accruals value } \\
\text { (Con-ACC). Con-ACC is calculated using income (before } \\
\text { extraordinary items) plus depreciation expense minus operating } \\
\text { cash flow divided by the average total assets. Next, multiply by } \\
\text { negative one. Previous studies (García Lara et al., 2009; Givoly \& } \\
\text { Hayn, 2000; Juliani \& Wardhani, 2018) use this formula as an } \\
\text { accounting conservatism indicator. }\end{array}$ \\
\hline
\end{tabular}

2 Board female The presence of women on the board of directors is measured using a dummy variable, following Abbott et al.'s (2012) research. Code 1 is given if a female board of directors is in the company, and code 0 otherwise.

3 Board The board expertise is measured using a percentage of the board of expertise directors with accounting (finance) expertise. 


\begin{tabular}{|c|c|c|}
\hline No & Variable & Indicator \\
\hline 4 & $\begin{array}{l}\text { Board } \\
\text { overconfidence }\end{array}$ & 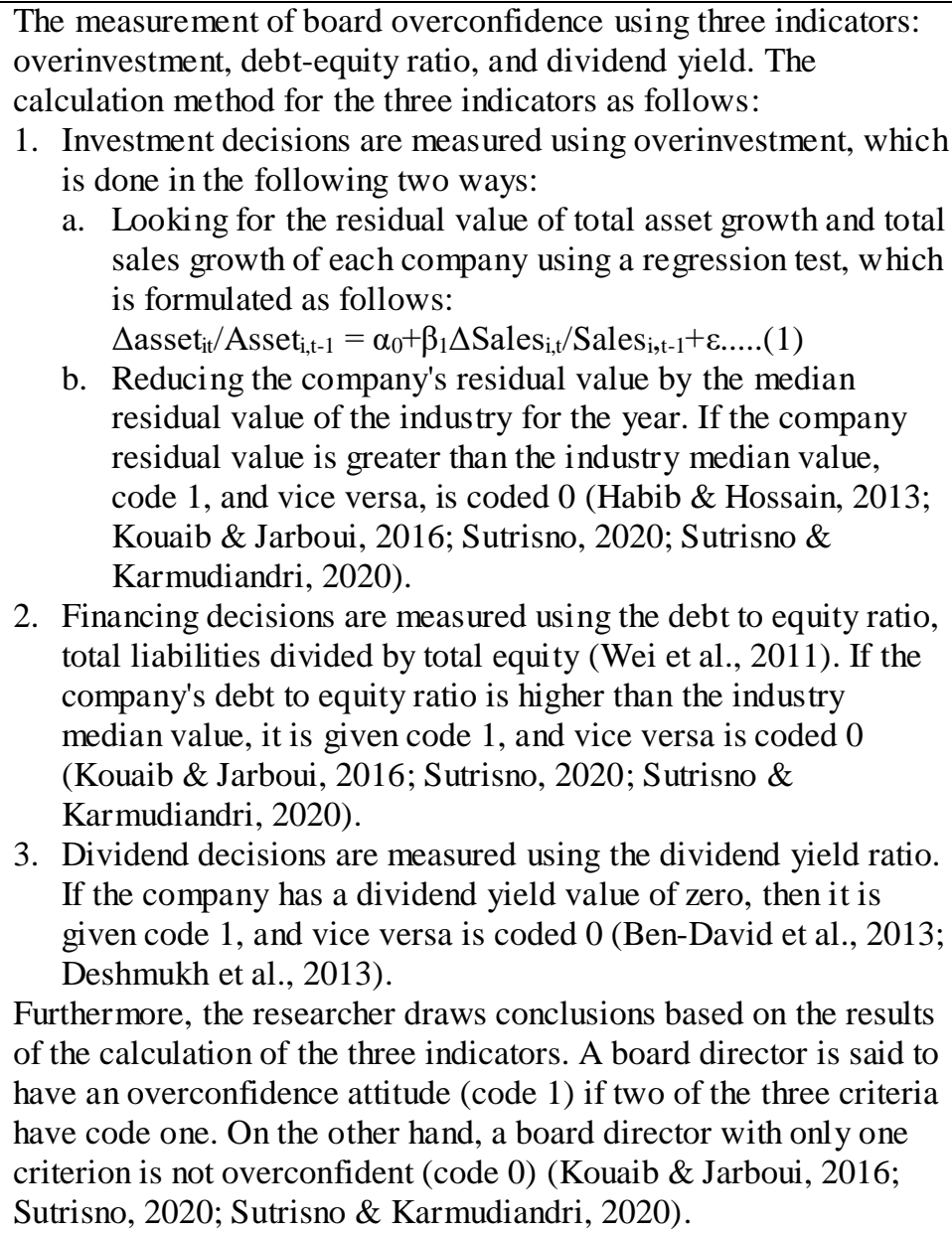 \\
\hline
\end{tabular}

5 Board size

6 Institutional ownership
The board size is measured using the number of board director members in the company.

This variable's measurement uses two indicators, including:

1. the ownership share by institutions. The measurement using a percentage of the share of financial institutions (banking, insurance, pension funds, and investments companies) (Cassell et al., 2017; Mehrani et al., 2017).

2. the number of institutional investors that hold company stock. This indicator is measured using the natural $\log$ of 1 plus the number of a financial institution that holds the common stock (Bushee, 1998; Cassell et al., 2017). 


\begin{tabular}{crl}
\hline No & Variable & \multicolumn{1}{c}{ Indicator } \\
\hline 7 & Profitability & $\begin{array}{l}\text { Measurement of profitability using the return on asset ratio, i.e., net } \\
\text { income divided by total assets. This measurement was used in } \\
\text { previous research (Cassell et al., 2017). }\end{array}$
\end{tabular}

8 Leverage Measurement of leverage using debt to equity ratio, i.e., total debt divided by total assets. This indicator following previous studies (Ahmed \& Duellman, 2013; Bushee, 1998; Liu \& Elayan, 2015).

9 Firm size Firm size is measured using the natural log of total assets, similar to previous studies (Ahmed \& Duellman, 2013).

10 Market to Market to book value is measured by dividing the market value of book value equity by the book value of equity ), following the previous studies (Ahmed \& Duellman, 2013; Cassell et al., 2017; Liu \& Elayan, 2015).

11 Litigation risk Litigation risk measurement is carried out using factor analysis on five variables: stock turnover, stock beta, leverage, liquidity, and company size. This measurement refers to previous research (Suryandari \& Priyanto, 2011). The results of factor analysis for the five variables formed three factors with Eigenvalues more significant than 1 and MSA values greater than 0.5 . Thus, the variables of stock turnover, stock beta, leverage, liquidity, and company size adequate to form a litigation ratio.

12 Sales growth Sales growth is measured by the percentage of annual growth in total sales). This indicator was similar to previous studies (Ahmed \& Duellman, 2013; Cassell et al., 2017).

13 Operating Measurement of operating uncertainty uses the standard deviation uncertainty of the natural log of revenue ( $\sigma$ revenue), as in previous studies (Ahmed \& Duellman, 2013). The measurement of revenue is used for three years, namely $\mathrm{t}-3$ to $\mathrm{t}-1$.

Source: Author calculation

\subsection{Data Analysis Technique}

This study uses Partial Least Squares to test the formulated hypotheses. The statistical model used for hypothesis testing is as follows:

Model 1:

Board characteristic, institutional ownership (IO percent), and accounting conservatis $m$ Con-ACC $=\beta_{0}+\beta_{1} B F+\beta_{2} B E+\beta_{3} B O+\beta_{4} B S+\beta_{5} B F^{*} \mathrm{IO}+\beta_{6} B E^{*} \mathrm{IO}+\beta_{7} \mathrm{BO} * \mathrm{IO}$ $+\beta_{8} \mathrm{BS} * \mathrm{IO}+\beta_{9}$ Pro $+\beta_{10} \mathrm{Lev}+\beta_{11} \mathrm{FS}+\beta_{12} \mathrm{MTB}+\beta_{13} \mathrm{LR}+\beta_{14} \mathrm{SG}+\beta_{15}$ $\mathrm{OU}$ 
Model 2:

Board characteristic, institutional ownership (IO count), and accounting conservatism

$$
\begin{aligned}
\text { Con-ACC }= & \beta_{0}+\beta_{1} \mathrm{BF}+\beta_{2} \mathrm{BE}+\beta_{3} \mathrm{BO}+\beta_{4} \mathrm{BS}+\beta_{5} \mathrm{BF} * \mathrm{IO}+\beta_{6} \mathrm{BE} * \mathrm{IO}+\beta_{7} \mathrm{BO} * \mathrm{IO} \\
& +\beta_{8} \mathrm{BS} * \mathrm{IO}+\beta_{9} \text { Pro }+\beta_{10} \mathrm{Lev}+\beta_{11} \mathrm{FS}+\beta_{12} \mathrm{MTB}+\beta_{13} \mathrm{LR}+\beta_{14} \mathrm{SG}+\beta_{15} \\
& \text { OU }
\end{aligned}
$$

Note:

Con-ACC = Accounting conservatism

$\mathrm{BF} \quad=$ Board female

$\mathrm{BE} \quad=$ Board expertise

$\mathrm{BO}=$ Board overconfidence

BS $\quad=$ Board size

IO = Institutional ownership

$\mathrm{BF}^{*} \mathrm{IO}=$ Interaction between board female and institutional ownership

$\mathrm{BE}^{*} \mathrm{IO}=$ Interaction between board expertise and institutional ownership

$\mathrm{BO} * \mathrm{IO}=$ Interaction between board overconfidence and institutional ownership

$\mathrm{BS} * \mathrm{IO}=$ interaction between board size and institutional ownership

Pro $\quad=$ profitability

Lev $\quad=$ leverage

FS $\quad=$ Firm size

MTB = market to book ratio

LR $\quad=$ Litigation risk

$\mathrm{SG} \quad=$ Sales growth

$\mathrm{OU} \quad=$ Operating uncertainty

\section{Results and Discussion}

\subsection{Descriptive Statistics}

This study used 354 observational data for three years of observation. The minimum, maximum, mean, and standard deviation values are presented in Table 2. 
Table 2

Descriptive Statistics

\begin{tabular}{lrrrrr}
\hline \multicolumn{1}{c}{ Variable } & N & Minimum & Maximum & Mean & $\begin{array}{c}\text { Std. } \\
\text { Deviation }\end{array}$ \\
\hline Board female & 354 & 0.00 & 1.00 & 0.45 & 0.49 \\
Board expertise & 354 & 13.00 & 100.00 & 42.51 & 19.39 \\
Board overconfidence & 354 & 0.00 & 1.00 & 0.49 & 0.50 \\
Board size & 354 & 2.00 & 14.00 & 4.96 & 2.18 \\
Institutional own (percentage) & 354 & 2.39 & 93.97 & 52.72 & 26.17 \\
Institutional own (counting) & 354 & 0.69 & 2.83 & 0.95 & 0.40 \\
Accounting conservatism & 354 & -0.99 & 0.77 & -0.15 & 0.28 \\
Profitability & 354 & -17.60 & 15.67 & 2.75 & 4.09 \\
Leverage & 354 & -6.58 & 20.94 & 2.92 & 3.37 \\
Firm size & 354 & 18.61 & 31.43 & 25.41 & 3.05 \\
Market to book ratio & 354 & 0.10 & 8.24 & 1.72 & 1.60 \\
Litigation risk & 354 & -1.95 & 3.67 & -0.05 & 1.01 \\
Sales growth & 354 & -0.95 & 3.82 & 0.10 & 0.39 \\
Operating uncertainty & 354 & 0.01 & 0.72 & 0.08 & 0.11 \\
Valid N (listwise) & 354 & & & & \\
\hline Sourc: & & & & &
\end{tabular}

Source: researcher calculation

Based on descriptive statistics data in Table 2, the average number of female members of board directors is moderate (45.00\%). The average of board expertise is 42.51\%. The board overconfidence also has a moderate value $(49.00 \%)$. The last characteristic, the average number of board members is five-person. Based on institutional ownership share, the average percentage ownership is $52.72 \%$. Meanwhile, the number of institutional investors is 0.95 . Table 2 also indicates that the accounting conservatism is relatively low, approximately -0.15 . In addition, this study uses seven control variables. The profitability variable has an average of 2.75 , while the average leverage value is 2.92. Based on firm size, the company sample average is 25.41 . Based on the market-to-book ratio, the average ratio is 1.72 . The average litigation risk is 0.05 . Besides, the company has an average sales growth and operating uncertainty ratio of 0.10 and 0.08 .

\subsection{The Hypotheses Result}

This study has eight hypothesis result testing that presented in Table 3.

Table 3 shows the test results of model 1 and model 2. Model 1 has an Adjusted RSquare value of $36.70 \%$. In the Model 2 test, the Adjusted R-Square value increased to 
$52.10 \%$. Therefore, both models have a moderate value. Table 3 presents the results of hypothesis testing for the two research models. The results show that board female ( $\mathrm{p}$ value $<0.01$ ) and board expertise ( $\mathrm{p}$-value $<0.05$ ) have a positive effect on accounting conservatism. Meanwhile, board overconfidence has a negative effect on accounting conservatism ( $\mathrm{p}$-value $<0.10$ ). Contrary, board size does not affect accounting conservatism, both in model 1 and model 2. Thus, the results support hypotheses 1,2 , and 3 but do not support hypothesis 4 .

Table 3

Hypothesis Test Results

\begin{tabular}{|c|c|c|c|c|c|c|c|}
\hline \multirow[b]{2}{*}{ Variables } & \multirow{2}{*}{$\begin{array}{c}\text { Hypothesis } \\
\text { Sign }\end{array}$} & \multicolumn{3}{|c|}{ Model 1 (IO_percent) } & \multicolumn{3}{|c|}{ Model 2 (IO_count) } \\
\hline & & $\begin{array}{l}\text { Original } \\
\text { sample }\end{array}$ & $\begin{array}{c}\mathrm{t}- \\
\text { statistics }\end{array}$ & p-value & $\begin{array}{l}\text { Original } \\
\text { sample }\end{array}$ & $\begin{array}{c}\mathrm{t}- \\
\text { statistics }\end{array}$ & p-value \\
\hline $\mathrm{BF}$ & + & 0.375 & 3.008 & $0.003 * * *$ & 0.425 & 3.770 & $0.000 * * *$ \\
\hline $\mathrm{BE}$ & + & 0.184 & 1.997 & $0.038 * *$ & 0.259 & 2.190 & $0.028 * *$ \\
\hline $\mathrm{BO}$ & - & -0.232 & 1.801 & $0.072 *$ & -0.165 & 1.671 & $0.095^{*}$ \\
\hline $\mathrm{BS}$ & + & 0.138 & 1.363 & 0.174 & 0.066 & 0.649 & 0.516 \\
\hline $\mathrm{BF} * \mathrm{IO}$ & + & 0.295 & 1.945 & $0.054 *$ & 0.304 & 2.720 & $0.007 * * *$ \\
\hline $\mathrm{BE} * \mathrm{IO}$ & + & 0.268 & 1.797 & $0.073 *$ & 0.290 & 1.877 & $0.064^{*}$ \\
\hline $\mathrm{BO} * \mathrm{IO}$ & - & -0.177 & 1.120 & 0.263 & -0.313 & 3.612 & $0.000 * * *$ \\
\hline $\mathrm{BS} * \mathrm{IO}$ & + & 0.038 & 0.202 & 0.840 & 0.006 & 0.047 & 0.963 \\
\hline Pro & & -0.049 & 0.458 & 0.647 & -0.012 & 0.155 & 0.877 \\
\hline Lev & & -0.013 & 0.089 & 0.929 & -0.008 & 0.062 & 0.950 \\
\hline FS & & -0.161 & 1.304 & 0.193 & -0.283 & 2.570 & $0.010 * * *$ \\
\hline MTB & & 0.117 & 0.986 & 0.325 & 0.104 & 0.931 & 0.352 \\
\hline LR & & 0.027 & 0.184 & 0.854 & 0.102 & 0.829 & 0.407 \\
\hline SG & & 0.121 & 1.108 & 0.268 & 0.080 & 0.700 & 0.484 \\
\hline $\mathrm{OU}$ & & -0.073 & 0.710 & 0.478 & -0.016 & 0.151 & 0.880 \\
\hline R Square & & & & 0.469 & & & 0.615 \\
\hline Adjusted R- & uare & & & 0.367 & & & 0.521 \\
\hline
\end{tabular}

Note: $* * *, * * *$ significance at $10 \%, 5 \%$, and $1 \%$

Source: researcher calculation

Table 3 also shows the results of the institutional ownership test as a moderating variable. In the first model, the institutional ownership variable uses the percentage of share ownership as an indicator, while the second model using the number of institutional investors. The results of statistical tests on both models prove that institutional ownership strengthens the positive influence of female board and board expertise on accounting conservatism ( $\mathrm{p}$-value $<0.01$ and $\mathrm{p}$-value $<0.10$ ). Therefore, the results of this test support hypotheses 5 and 6 . 
However, inconsistent results are shown in the board overconfidence variable test. In Model 1, the results of the moderation test show that institutional ownership fails to moderate the relationship between board overconfidence and accounting conservatism. On the other hand, when using different indicators in Model 2, the interaction between board overconfidence and institutional ownership has a negative effect on accounting conservatism ( $\mathrm{p}$-value $<0.01$ ). The results only support hypothesis 7 in Model 2 but not in Model 1. Likewise, the results of the moderation test for the board size variable. Table 3 shows that institutional ownership cannot moderate the relationship between board size and accounting conservatism, both in Model 1 and Model 2. Thus, this hypothesis does not support hypothesis 8 in both research models.

The results of statistical tests for the seven control variables show that the variables of profitability, leverage, market to book value, litigation risk, sales growth, and operating uncertainty do not affect accounting conservatism. However, firm size variable affects accounting conservatism.

\subsection{Discussion}

\subsubsection{Board Female and Accounting Conservatism}

The first hypothesis of the testing result reveals that the female board positively affects accounting conservatism. The presence of women in top positions also influences the company's financial decision-making. In the financial and economic context, women are often seen as not assertive in making financial decisions. This condition occurs because women feel less confident and less competent in making decisions (Barber \& Odean, 2001; Powell \& Ansic, 1997). Business literature confirms that women tend to be conservative or risk-averse (Francis et al., 2015; Huang \& Kisgen, 2013; Vermeir \& Van Kenhove, 2008). Some companies with high risk deliberately choose female CEOs to modulate risk. In this condition, female CEOs will avoid high-risk investment and financing opportunities (Martin et al., 2009; Zeng \& Wang, 2015). In the accounting conservatism context, female executive boards have a more conservative attitude. This character keeps women from engaging in unethical accounting practices, such as earnings management or tax aggressiveness (Francis et al., 2015; Ho et al., 2015). Therefore, companies led by female directors are considered 
to have higher earnings quality (Francis et al., 2015; Krishnan \& Parsons, 2008). Thus, these results prove that women's presence on the board of directors increases accounting conservatism.

\subsubsection{Board Expertise and Accounting Conservatism}

The results of the second hypothesis test reveal that board expertise has a positive effect on accounting conservatism. The results support the formulated hypothesis. In the context of financial reporting, a director with accounting expertise makes a substantial contribution to financial decision-making, such as operational, investment, and dividend policies (Dill, 2013). Based on their expertise, board members supervise the process of preparing financial reports intensively. The director has the authority to determine reporting targets and timing to prevent possible reporting failures (García-Sánchez et al., 2017; Geiger \& North, 2006). The research results by Badolato et al. (2014) suggest that financial expertise increases the effectiveness of internal control while reducing the potential for earnings management. Therefore, directors with accounting or financial expertise positively impact the quality of financial reporting, including conservative financial statements (García-Sánchez et al., 2017). These results support previous findings that financial experts positively affect accounting conservatism and decisionmaking (García-Sánchez et al., 2017). However, this result contradicts Hu et al. (2017) research that CEOs with accounting backgrounds have lower accounting conservatism.

\subsubsection{Board Overconfidence and Accounting Conservatism}

Table 3 reveals that board overconfidence has an effect on accounting conservatism at the $90 \%$ confidence level. Board overconfidence is one of the challenges in conservative accounting reporting practice (Chouaibi \& Chiekh, 2017). The overconfidence attitude accelerates the recognition of profits or benefits. This attitude also causes management to underestimate the number of liabilities or losses and even delay recognizing losses. This overconfidence behavior eventually creates optimism in determining and recording the value of the company's assets. As a result, overconfidence behavior directs management to aggressive financial reporting (Ahmed $\&$ Henry, 2012). Thus, this study supports the previous result that there is a negative relationship between overconfidence board and accounting conservatism (Ahmed \& 
Duellman, 2013; Chouaibi \& Chiekh, 2017; Hwang et al., 2015). Many literary works reveal that board overconfidence reduces accounting conservatism (Ahmed \& Duellman, 2013; Chouaibi \& Chiekh, 2017; Hwang, Cha, \& Yeo, 2015).

\subsubsection{Board Size and Accounting Conservatism}

The fourth hypothesis result indicates that the board size does not affect accounting conservatism. In a corporate governance context, the board of directors' size is one of the conservative financial reporting determinants. Agency theory explains that the large board size is expected to minimize agency conflicts by applying conservative accounting principles. However, the results of hypothesis testing show contradictory results. This condition is because the determination of the size of the board has not been based on the company's actual needs. Companies with large boards of directors tend to have difficulty communicating and coordinating (El-habashy, 2019). As a result, the $\mathrm{BoD}$ cannot manage resources effectively, including failing to apply the principles of accounting conservatism in financial reporting. In contrast, the small board is considered to reflect weak corporate governance, and it cannot improve the quality of financial reports. These statistical results support previous empirical studies that found no significant effect between board size and accounting conservatism (El-habashy, 2019; Elshandidy \& Hassanein, 2014).

\subsubsection{Board Female, Institutional Ownership, and Accounting Conservatism}

The fifth hypothesis testing result indicates that institutional ownership plays a role in strengthening female boards' relationship and accounting conservatism. In implementing corporate governance, institutional investors focus more on the long-term benefits of investing, and they have higher demands to increase accounting conservatism (Majeed et al., 2017). Institutional shareholders also generally have higher skills to reduce opportunistic management behavior and earnings management (Farooq \& El Jai, 2012; Lin et al., 2014). This characteristic following a woman's mindset that tends to be conservative. Female executives are more sensitive to the risk that the company must bear. It makes them avoid overstatement or aggressive accounting reporting (Francis et al., 2015). This conservative mindset motivates female directors to 
refuse the fraudulent behavior firmly. Thus, institutional investors strengthen the positive influence of women's boards on accounting conservatism.

\subsubsection{Board Expertise, Institutional Ownership, and Accounting Conservatism}

The sixth hypothesis testing result also discloses that institutional ownership could strengthen the positive influence of board expertise on accounting conservatism. Institutional ownership is the largest shareholder in the company. Significant ownership motivates institutional investors to perform an influential supervisory role. Institutional investors can continuously monitor and provide advice to management to conduct conservative financial reporting. Meanwhile, directors with accounting (finance) expertise serve the interests of shareholders to the fullest (Güner et al., 2008). Based on accounting or finance expertise, the board helps improve the quality of financial reporting through conservative accounting practices. In addition, directors with accounting expertise do not accelerate (delay) the disclosure of good news (bad news) presented in the income reporting. Thus, institutional ownership and boards with accounting expertise in preparing financial statements increase accounting conservatism.

\subsubsection{Board Overconfidence, Institutional Ownership, and Accounting Conservatism}

This seventh hypothesis aims to study institutional ownership's role in moderating the relationship between board overconfidence and accounting conservatism. However, the results of statistical tests do not support the formulated hypothesis. In Model 1, the institutional ownership variable is measured using the percentage of institutional share ownership. Theoretically, institutional share ownership can perform a practical monitoring function because it has a substantial percentage of share ownership. However, this study has not ensured the effectiveness of their monitoring function (Mehrani et al., 2017). Some studies reveal that institutional investors are active monitors. Meanwhile, other studies argue that institutional investors may not fully play an active role due to several reasons such as the existence of "free riders", inadequate experience, or compromises with management (Mehrani et al., 2017). Likewise, the results of this study indicate the failure of institutional investors to reduce the negative effect of board overconfidence on accounting conservatism. It is because institutional 
investors have not performed their supervisory function adequately, particularly in financial reporting. As a result, overconfidence boards of directors tend to be aggressive in making high-risk financial decisions (Deshmukh et al., 2013; Pikulina et al., 2017). In addition, overly optimistic executives tend to report higher earnings than other executives (Almaleki et al., 2021). Thus, as proxied by a high percentage of share ownership, institutional ownership cannot reduce the negative effect of board overconfidence on accounting conservatism.

Contrary to the results of the moderation test in model 1 , the results of the moderation test in model 2 reveal that the amount of institutional ownership can reduce the negative effect of board overconfidence on accounting conservatism. This condition indicates that institutional investors have played an active role in monitoring management performance, even though they have small shareholdings. Institutional ownership as intense external monitoring is seen as reducing the impact of board overconfidence on accounting conservatism. Also, institutional shareholders can control managerial behavior by cutting compensation, eliminating bonuses, and firing managers (Cullinan et al., 2012). Thus, companies with a large number of institutional investors can demand conservative accounting information reporting.

\subsubsection{Board Size, Institutional Ownership, and Accounting Conservatism}

The eight hypothesis test results indicate that institutional ownership fails as a moderator between board size and accounting conservatism relationship, both for two models. Institutional ownership generally has majority shares, and they are motivated to be actively involved in corporate governance (Ahmed \& Duellman, 2007; Lin et al., 2014). Theoretically, this authority also allows institutional investors to pressure the directors to apply conservative accounting principles (Firth et al., 2016) to reduce agency costs. A prominent director also makes it easier to coordinate with institutional investors regarding the company's management. Nevertheless, in this study, the large size of directors does not guarantee that they can commit their functions effectively, including meeting the demands of institutional investors to implement conservative accounting practices. Many directors experience difficulties in coordinating and communicating in managing company operations (El-habashy, 2019). Besides, a larger 
board size allows for interdependence among board members in strategic decisionmaking. In accounting conservatism practice, large boards are prone to disputes that lead to internal conflicts. Based on these conditions, institutional ownership failed to moderate the relationship between board size and accounting conservatism. Thus, institutional ownership strengthens the relationship between the board size and the conservatism of financial statements.

\section{Conclusion, Implication, and Limitation}

\subsection{Conclusion}

This study aims to explore the role of board characteristics, namely board female, board expertise, board overconfidence, and board size in accounting conservatism practices. This study also examines institutional ownership as a moderator that uses two indicators, including a percentage of share and the number of institutional investors. Based on agency theory, institutional ownership and external monitoring in accounting conservatism practice. This study's results support the idea that board female and board expertise increase accounting conservatism, while board overconfidence reduces it. However, there is no relationship between board size and accounting conservatism. This study also indicates that institutional ownership strengthens the relationship between board females and board expertise to accounting conservatism. Contrary, institutional ownership fails as moderating between board size and accounting conservatism relationship. In testing the board overconfidence variable, the percentage of institutional ownership variable cannot as moderating. Nevertheless, the interaction between board overconfidence and the number of institutional investors has a negative effect on accounting conservatism.

\subsection{Implication and Limitation}

The results have implications for academics, practitioners, and regulators. For academics, this empirical finding implies that accounting conservatism is an effective strategy to reduce agency conflicts in companies. Institutional ownership also an effective governance mechanism to improve financial reporting quality. However, the effectiveness of institutional roles is determined by the percentage of share ownership 
and the number of institutional investors involved in share ownership in the company. This study implies that the interaction of the board characteristic with the number of institutional investors results in a more effective monitoring function. For practitioners, accounting conservatism is a signal for management to consistently apply the principle of prudence in assessing risks or possible financial failures in the future. Shareholders also should consider the board of directors' characteristics in determining the company's strategic position and financial decision-making. In addition, stakeholders can streamline the role of institutional investors as external monitoring of the board of directors' performance. For regulators, applying accounting conservatism is an effective strategy to improve corporate governance practices. Regulators should also address the characteristics of corporate governance to produce effective regulations or policies.

Overall, this study's results succeeded in proving the role of institutional ownership as a moderator in the board characteristic relationship and accounting conservatism. Nevertheless, this study has two research limitations. First, this study only uses one measurement indicator of accounting conservatism, namely the accrual value. The results of statistical tests may give different results if researchers use other indicators of accounting conservatism. Future research can be using other measurements, such as asymmetric timeliness of earnings measure (Basu, 1997) or market to book (Savitri, 2016). Second, this study uses a dummy variable as an indicator for the board female. This indicator cannot represent the variation in the role of women in top management positions. Future research can consider using the proportion of women (percentage) on the board of directors.

\section{Reference}

Abbott, L. J., Parker, S., \& Presley, T. J. (2012). Female board presence and the likelihood of financial restatement. Accounting Horizons, 26(4), 607-629. https://doi.org/10.2308/acch-50249

Abdul-Manaf, K. B., Amran, N. A., \& Zainol-Abidin, A. (2014). Board size and accounting conservatism of Malaysian listed firms. Australian Journal of Basic and Applied Sciences, 8(23), 207-211. http://repo.uum.edu.my/13983/1/Jou.pdf 
Affes, H., \& Sardouk, H. (2016). Accounting conservatism and corporate performance: The moderating effect of the board of directors. Journal of Business and Financial Affairs, 5(2), 1-8. https://doi.org/10.4172/2167-0234.1000187

Ahmed, A. S., Billings, B. K., Morton, R. M., \& Stanford-Harris, M. (2002). The role of accounting conservatism in mitigating bondholder-shareholder conflicts over dividend policy and in reducing debt costs. The Accounting Review, 77(4), 867-890. https://doi.org/10.2308/accr.2002.77.4.867

Ahmed, A. S., \& Duellman, S. (2007). Accounting conservatism and board of director characteristics: An empirical analysis. Journal of Accounting and Economics, 43(2), 411-437. https://doi.org/10.1016/j.jacceco.2007.01.005

Ahmed, A. S., \& Duellman, S. (2013). Managerial overconfidence and accounting conservatism. Journal of Accounting Research, 51(1), 1-30. https://doi.org/10.1111/j.1475679X.2012.00467.x

Ahmed, K., \& Henry, D. (2012). Accounting conservatism and voluntary corporate governance mechanisms by Australian firms. Accounting \& Finance, 52(3), 631-662. https://doi.org/10.1111/j.1467-629X.2011.00410.x

Alkurdi, A., Al-Nimer, M., \& Dabaghia, M. (2017). Accounting conservatism and ownership structure effect: Evidence from industrial and financial Jordanian listed companies. International Journal of Economics and Financial Issues, 7(2), 608-619. https://www.ammanu.edu.jo/english/pdf/StaffResearch/business/10101/Accounting Conservatism and Ownership Structure Effect Evidence from Ind ustrial and Financial Jordanian Listed.pdf

Almaleki, M., Salehi, M., \& Moradi, M. (2021). The relationship between narcissism, managerial overconfidence, and comparability of financial statements of listed companies. Journal of Facilities Management, ahead-of-print, ahead-of-print. https://doi.org/10.1108/JFM-01-2021-0002

Almutairi, A. R., \& Quttainah, M. A. (2019). Corporate governance and accounting conservatism in Islamic banks. Thunderbird International Business Review, 61(5), 745-764. https://doi.org/10.1002/tie.22063

Anderson, R. C., Mansi, S. A., \& Reeb, D. M. (2004). Board characteristics, accounting report integrity, and the cost of debt. Journal of Accounting and Economics, 37(3), 315-342. https://doi.org/10.1016/j.jacceco.2004.01.004

Badolato, P. G., Donelson, D. C., \& Ege, M. (2014). Audit committee financial expertise and earnings management: The role of status. Journal of Accounting and Economics, 58(2), 208-230. https://doi.org/10.1016/j.jacceco.2014.08.006

Ball, R. (2001). Infrastructure requirements for an economically efficient system of public financial reporting and disclosure. Brookings-Wharton Papers on Financial Services, 2001(1), 127-169. https://doi.org/10.1353/pfs.2001.0002 
Barber, B. M., \& Odean, T. (2001). Boys will be boys: Gender, overconfidence, and common stock investment. The Quarterly Journal of Economics, 116(1), 261-292. https://doi.org/10.1162/003355301556400

Basu, S. (1997). The conservatism principle and the as ymmetric timeliness of earnings1. Journal of Accounting and Economics, 24(1), 3-37. https://doi.org/10.1016/S01654101(97)00014-1

Basu, S., \& Liang, Y. I. (2019). Director-liability-reduction laws and conditional conservatism. Journal of Accounting Research, 57(4), 889-917. https://doi.org/10.1111/1475679X.12267

Ben-David, I., Graham, J. R., \& Harvey, C. R. (2013). Managerial miscalibration. The Quarterly Journal of Economics, 128(4), 1547-1584. https://doi.org/10.1093/qje/qjt023

Boussaid, N., Hamza, T., \& Sougne, D. (2015). Corporate board attributes and conditional accounting conservatism: Evidence from French firms. Journal of Applied Business Research (JABR), 31(3), 871-890. https://doi.org/10.19030/jabr.v31i3.9224

Bushee, B. J. (1998). The influence of institutional investors on myopic R\&D investment behavior. The Accounting Review, 73(3), 305-333. http://www.jstor.org/stable/248542

Cassell, C. A., Drake, M. S., \& Dyer, T. A. (2017). Auditor litigation risk and the number of institutional investors. AUDITING: A Journal of Practice \& Theory, 37(3), 71-90. https://doi.org/10.2308/ajpt-51832

Chi, W., Liu, C., \& Wang, T. (2009). What affects accounting conservatism: A corporate governance perspective. Journal of Contemporary Accounting \& Economics, 5(1), 47-59. https://doi.org/10.1016/j.jcae.2009.06.001

Chouaibi, J., \& Chiekh, S. (2017). Effects of the specific characteristics of the CEO on accounting conservatism: A study in the US context. International Journal of Auditing Technology, 3(4), 297-317. https://doi.org/10.1504/IJAUDIT.2017.091323

Chung, H. H., Wynn, J. P., \& Yi, H. (2013). Litigation risk, accounting quality, and investment efficiency. Advances in Accounting, 29(2), 180-185. https://doi.org/10.1016/j.adiac.2013.09.009

Coles, J. L., Daniel, N. D., \& Naveen, L. (2008). Boards: Does one size fit all? Journal of Financial Economics, 87(2), 329-356. https://doi.org/10.1016/j.jfineco.2006.08.008

Cullinan, C. P., Wang, F., Wang, P., \& Zhang, J. (2012). Ownership structure and accounting conservatism in China. Journal of International Accounting, Auditing, and Taxation, 21(1), 1-16. https://doi.org/10.1016/j.intaccaudtax.2012.01.001

Darrat, A. F., Gray, S., Park, J. C., \& Wu, Y. (2014). Corporate governance and bankruptcy risk. Journal of Accounting, Auditing \& Finance, 31(2), 163-202. https://doi.org/10.1177/0148558X14560898 
Deshmukh, S., Goel, A. M., \& Howe, K. M. (2013). CEO overconfidence and dividend policy. Journal of Financial Intermediation, 22(3), 440-463. https://doi.org/10.1016/j.jfi.2013.02.003

Dill, K. (2013). CFOs have bigger roles than ever before-and they like it that way. Forbes. https://www.forbes.com/sites/kathryndill/2013/08/02/cfos-have-bigger-roles-thaneverbefore-\%0Aand-they-like-it-that-way/\#52ba26fb3c7c

Ebrahim, A., \& Fattah, T. A. (2015). Corporate governance and initial compliance with IFRS in emerging markets: The case of income tax accounting in Egypt. Journal of International Accounting, Auditing, and Taxation, 24(1), 46-60. https://doi.org/10.1016/j.intaccaudtax.2015.02.003

Eisenberg, T., Sundgren, S., \& Wells, M. T. (1998). Larger board size and decreasing firm value in small firms. Journal of Financial Economics, 48(1), 35-54. https://doi.org/10.1016/S0304-405X(98)00003-8

El-habashy, H. A. (2019). The effect of corporate governance attributes on accounting conservatism in Egypt. Academy of Accounting and Financial Studies Journal, 23(3), 1-18. https://doi.org/10.5539/ibr.v11n7p130

Elshandidy, T., \& Hassanein, A. (2014). Do IFRS and board of directors' independence affect accounting conservatism? Applied Financial Economics, 24(16), 1091-1102. https://doi.org/10.1080/09603107.2014.924291

Enache, L., \& García-Meca, E. (2019). Board composition and accounting conservatism: The role of business experts, support specialists, and community influentials. Australian Accounting Review, 29(1), 252-265. https://doi.org/10.1111/auar.12279

Farizal, M. N., Kamran, A., \& Xu-Dong, J. (2017). Accounting conservatism, corporate governance, and political connections. Asian Review of Accounting, 25(2), 288-318. https://doi.org/10.1108/ARA-04-2016-0041

Farooq, O., \& El Jai, H. (2012). Ownership structure and earnings management: Evidence from the Casablanca stock exchange. International Research Journal of Finance and Economics, 84(1), 95-105. http://www.internationalresearchjournaleconomics.com

Firth, M., Gao, J., Shen, J., \& Zhang, Y. (2016). Institutional stock owners hip and firms' cash dividend policies: Evidence from China. Journal of Banking \& Finance, 65(4), 91107. https://doi.org/10.1016/j.jbankfin.2016.01.009

Francis, B., Hasan, I., Park, J. C., \& Wu, Q. (2015). Gender differences in financial reporting decision making: Evidence from accounting conservatism. Contemporary Accounting Research, 32(3), 1285-1318. https://doi.org/10.1111/1911-3846.12098

Francis, B., Hasan, I., \& Wu, Q. (2013). The benefits of conservative accounting to shareholders: Evidence from the financial crisis. Accounting Horizons, 27(2), 319-346. https://doi.org/10.2308/acch-50431 
García-Sánchez, I.-M., Martínez-Ferrero, J., \& García-Meca, E. (2017). Gender diversity, financial expertise, and its effects on accounting quality. Management Decision, 55(2), 347-382. https://doi.org/10.1108/MD-02-2016-0090

García Lara, J. M., García Osma, B., \& Penalva, F. (2009). Accounting conservatism and corporate governance. Review of Accounting Studies, 14(1), 161-201. https://doi.org/10.1007/s11142-007-9060-1

Geiger, M. A., \& North, D. S. (2006). Does hiring a new CFO change things? An investigation of changes in discretionary accruals. The Accounting Review, 81(4), 781-809. https://doi.org/10.2308/accr.2006.81.4.781

Givoly, D., \& Hayn, C. (2000). The changing time-series properties of earnings, cash flows, and accruals: Has financial reporting become more conservative? Journal of Accounting and Economics, 29(3), 287-320. https://doi.org/10.1016/S0165-4101(00)00024-0

Givoly, D., Hayn, C. K., \& Natarajan, A. (2007). Measuring reporting conservatism. The Accounting Review, 82(1), 65-106. https://doi.org/10.2308/accr.2007.82.1.65

Graham, J. R., Harvey, C. R., \& Rajgopal, S. (2005). The economic implications of corporate financial reporting. Journal of Accounting and Economics, 40(1), 3-73. https://doi.org/10.1016/j.jacceco.2005.01.002

Gul, F. A., Srinidhi, B., \& Ng, A. C. (2011). Does board gender diversity improve the informativeness of stock prices? Journal of Accounting and Economics, 51(3), 314338. https://doi.org/10.1016/j.jacceco.2011.01.005

Güner, A. B., Malmendier, U., \& Tate, G. (2008). Financial expertise of directors. Journal of Financial Economics, 88(2), 323-354. https://doi.org/10.1016/j.jfineco.2007.05.009

Habib, A., \& Hossain, M. (2013). CEO/CFO characteristics and financial reporting quality: A review. Research in Accounting Regulation, 25(1), 88-100. https://doi.org/10.1016/j.racreg.2012.11.002

Hamdan, A. M. M. (2020). Audit committee characteristics and earnings conservatism in banking sector: Empirical study from GCC. Afro-Asian Journal of Finance and Accounting, 10(1), 1-23. https://doi.org/10.1504/AAJFA.2020.104401

Heaton, J. B. (2002). Managerial optimism and corporate finance. Financial Management, 31(2), 33-45. https://doi.org/10.2307/3666221

Hendro, H., \& Wardhani, R. (2015). Pengaruh agency cost of free cash flow terhadap tingkat konservatisme dan pengujian efek moderasi kebijakan hutang, pendistribusian kas, persistensi kas, dan tata kelola perusahaan. Jurnal Akuntansi Dan Keuangan, 17(1), 41-56. https://doi.org/10.9744/jak.17.1.41-56

Hilary, G., \& Hsu, C. (2011). Endogenous overconfidence in managerial forecasts. Journal of Accounting and Economics, 31(3), 300-313. https://doi.org/10.1016/j.jacceco.2011.01.002 
Ho, S. S. M., Li, A. Y., Tam, K., \& Zhang, F. (2015). CEO gender, ethical leadership, and accounting conservatism. Journal of Business Ethics, 127(2), 351-370. https://doi.org/10.1007/s10551-013-2044-0

Hu, N., Huang, R., Li, X., \& Liu, L. (2017). The impact of CEOs' accounting backgrounds on earnings management and conservatism. Journal of Centrum Cathedra, 10(1), 4-24. https://doi.org/10.1108/JCC-10-2016-0016

Huang, J., \& Kisgen, D. J. (2013). Gender and corporate finance: Are male executives overconfident relative to female executives? Journal of Financial Economics, 108(3), 822-839. https://doi.org/10.1016/j.jfineco.2012.12.005

Hwang, K., Cha, M., \& Yeo, Y. (2015). Does managerial overconfidence influence financial reporting? The relationship between overinvestment and conditional conservatism. Review of Integrative Business and Economics Research, 4(1), 273. https://sibresearch.org/uploads/3/4/0/9/34097180/riber_h14-211_273-298.pdf

Jensen, M. C., \& Meckling, W. H. (1976). Theory of the firm: Managerial behavior, agency costs, and ownership structure. Journal of Financial Economics, 3(4), 305-360. https://doi.org/10.1016/0304-405X(76)90026-X

Juliani, D., \& Wardhani, R. (2018). Pengaruh konservatisme terhadap efisiensi investasi dan agency cost sebagai variabel moderasi pada perusahaan yang melakukan merger dan akuisisi di Asia Tenggara. Jurnal Akuntansi, 22(2), 266-278. https://doi.org/10.24912/ja.v22i2.352

Kao, H.-S., \& Chu, T.-W. (2016). Audit committee, supervisor system, and accounting conservatism. International Research Journal of Applied Finance, 7(9), 202-219. https://doi.org/10.0709/article-1

Kiel, G. C., \& Nicholson, G. J. (2003). Board composition and corporate performance: How the Australian experience informs contrasting theories of corporate governance. Corporate Governance: An International Review, 11(3), 189-205. https://doi.org/10.1111/1467-8683.00318

Kouaib, A., \& Jarboui, A. (2016). The moderating effect of CEO profile on the link between cutting R\&D expenditures and targeting to meet/beat earnings benchmarks. The Journal of High Technology Management Research, 27(2), 140-160. https://doi.org/10.1016/j.hitech.2016.10.005

Krishnan, G. V, \& Parsons, L. M. (2008). Getting to the bottom line: An exploration of gender and earnings quality. Journal of Business Ethics, 78(1), 65-76. https://doi.org/10.1007/s10551-006-9314-Z

Krishnan, G. V, \& Visvanathan, G. (2008). Does the SOX definition of an accounting expert matter? The association between audit committee directors' accounting expertise and accounting conservatism. Contemporary Accounting Research, Forthcoming, 25(3), 827-857. https://doi.org/10.1506/car.25.3.7 
Labelle, R., Makni Gargouri, R., \& Francoeur, C. (2010). Ethics, diversity management, and financial reporting quality. Journal of Business Ethics, 93(2), 335-353. https://doi.org/10.1007/s10551-009-0225-7

Levi, M. D., Li, K., \& Zhang, F. (2008). Mergers and acquisitions: The role of gender. Available at SSRN 1123735. https://papers.ssrn.com/sol3/papers.cfm?abstract_id=1123735

Libby, R., \& Rennekamp, K. (2012). Self-serving attribution bias, overconfidence, and the issuance of management forecasts. Journal of Accounting Research, 50(1), 197-231. https://doi.org/10.1111/j.1475-679X.2011.00430.x

Lin, F., Wu, C.-M., Fang, T.-Y., \& Wun, J.-C. (2014). The relations among accounting conservatism, institutional investors, and earnings manipulation. Economic Modelling, 37(2), 164-174. https://doi.org/10.1016/j.econmod.2013.10.020

Lin, L. (2016). Institutional ownership composition and accounting conservatism. Review of Quantitative Finance and Accounting, 46(2), 359-385. https://doi.org/10.1007/s11156-014-0472-2

Liu, Z., \& Elayan, F. A. (2015). Litigation risk, information asymmetry, and conditional conservatism. Review of Quantitative Finance and Accounting, 44(4), 581-608. https://doi.org/10.1007/s11156-013-0428-y

Majeed, M. A., Xian-zhi Zhang, \& Wang, Z. (2017). Product market competition, regulatory changes, ownership structure, and accounting conservatism: Evidence from China. Chinese Management Studies, 11(4), 658-688. https://doi.org/10.1108/CMS-122016-0248

Malmendier, U., \& Tate, G. (2015). Behavioral CEOs: The role of managerial overconfidence. Journal of Economic Perspectives, 29(4), 37-60. https://doi.org/10.1257/jep.29.4.37

Martin, A. D., Nishikawa, T., \& Williams, M. A. (2009). CEO gender: Effects on valuation and risk. Quarterly Journal of Finance and Accounting, 48(3), 23-40. http://www.jstor.org/stable/23075251

Marzuki, M. M., Wahab, E. A. A., \& Haron, H. (2016). Corporate governance and earnings conservatism in Malaysia. Accounting Research Journal, 29(4), 391-412. https://doi.org/10.1108/ARJ-04-2014-0043

Mehrani, S., Moradi, M., \& Eskandar, H. (2017). Institutional ownership type and earnings quality: Evidence from Iran. Emerging Markets Finance and Trade, 53(1), 54-73. https://doi.org/10.1080/1540496X.2016.1145114

Muttakin, M. B., Khan, A., \& Tanewski, G. (2019). CFO tenure, CFO board membership, and accounting conservatism. Journal of Contemporary Accounting \& Economics, 15(3), 100165. https://doi.org/10.1016/j.jcae.2019.100165 
Nasr, M. A., \& Ntim, C. G. (2018). Corporate governance mechanisms and accounting conservatism: Evidence from Egypt. Corporate Governance: The International Journal of Business in Society, 18(3), 386-407. https://doi.org/10.1108/CG-05-20170108

Peni, E., \& Vähämaa, S. (2010). Female executives and earnings management. Managerial Finance, 36(7), 629-645. https://doi.org/10.1108/03074351011050343

Pikulina, E., Renneboog, L., \& Tobler, P. N. (2017). Overconfidence and investment: An experimental approach. Journal of Corporate Finance, 43(4), 175-192. https://doi.org/10.1016/j.jcorpfin.2017.01.002

Platt, H., \& Platt, M. (2012). Corporate board attributes and bankruptcy. Journal of Business Research, 65(8), 1139-1143. https://doi.org/10.1016/j.jbusres.2011.08.003

Powell, M., \& Ansic, D. (1997). Gender differences in risk behaviour in financial decisionmaking: An experimental analysis. Journal of Economic Psychology, 18(6), 605-628. https://doi.org/10.1016/S0167-4870(97)00026-3

Ramalingegowda, S., \& Yu, Y. (2012). Institutional ownership and conservatism. Journal of Accounting and Economics, 53(1), 98-114. https://doi.org/10.1016/j.jacceco.2011.06.004

Ramsheh, M., \& Molanzari, M. (2014). Managerial overconfidence and accounting conservatism. Journal of Accounting of Knowledge, 5(16), 55-79.

Roll, R. (1986). The hubris hypothesis of corporate takeovers. The Journal of Business, 59(2), 197-216. http://www.jstor.org/stable/2353017

Roychowdhury, S., \& Watts, R. L. (2007). Asymmetric timeliness of earnings, market-to-book, and conservatism in financial reporting. Journal of Accounting and Economics, 44(1), 2-31. https://doi.org/10.1016/j.jacceco.2006.12.003

Rustiarini, N. W., \& Merawati, L. K. (2021). Fraud and whistleblowing intention: Organizational justice perspective. Riset Akuntansi Dan Keuangan Indonesia, 5(3), 210-222. https://doi.org/10.23917/reaksi.v5i3.11970

Savitri, E. (2016). Konservatisme Akuntansi: Cara Pengukuran, Tinjauan Empiris, dan Faktorfaktor yang Mempengaruhinya (First). Pustaka Sahila.

Schrand, C. M., \& Zechman, S. L. C. (2012). Executive overconfidence and the slippery slope to financial misreporting. Journal of Accounting and Economics, 53(1), 311-329. https://doi.org/10.1016/j.jacceco.2011.09.001

Song, F. (2015). Ownership structure and accounting conservatism: A literature review. Modern Economy, 6(04), 478. https://doi.org/10.4236/me.2015.64046 
Song, M., Oshiro, N., \& Shuto, A. (2016). Predicting accounting fraud: Evidence from Japan. The Japanese Accounting Review, 6(2016), 17-63. https://doi.org/10.11640/tjar.6.2016.01

Stephenson, C., \& Nt, M. (2004). Leveraging diversity to maximum advantage: The business case for appointing more women to boards. Ivey Business Journal, 69(1), 1-5. https://wgfpa.org/wp-content/uploads/diversity.pdf

Sultana, N. (2015). Audit committee characteristics and accounting conservatism. International Journal of Auditing, 19(2), 88-102. https://doi.org/10.1111/ijau.12034

Suryandari, E., \& Priyanto, R. E. (2011). Pengaruh risiko litigasi dan tingkat kesulitan keuangan perusahaan terhadap hubungan antara konflik kepentingan dan konservatisme akuntansi. Journal of Accounting and Investment, 12(2), 161-174. https://journal.umy.ac.id/index.php/ai/article/view/681

Sutrisno, P. (2020). Are CEO overconfidence and audit firm size related to tax avoidance? GATR Accounting and Finance Review, 5(2), 56-65. https://doi.org/10.35609/afr.2020.5.2(3)

Sutrisno, P., \& Karmudiandri, A. (2020). CEO overconfidence, founder restatement of financial reporting. International Journal of Business, Economics, and Law, 23(1), 192-198. https://www.ijbel.com/wp-content/uploads/2020/12/IJBEL23-249.pdf

Vermeir, I., \& Van Kenhove, P. (2008). Gender differences in double standards. Journal of Business Ethics, 81(2), 281-295. https://doi.org/10.1007/s10551-007-9494-1

Wang, C., Xie, F., \& Zhu, M. (2015). Industry expertise of independent directors and board monitoring. Journal of Financial and Quantitative Analysis, 50(5), 929-962. https://doi.org/10.1017/S0022109015000459

Watts, R. L. (2003). Conservatism in accounting part I: Explanations and implications. Accounting Horizons, 17(3), 207-221. https://doi.org/10.2308/acch.2003.17.3.207

Wei, J., Min, X., \& Jiaxing, Y. (2011). Managerial overconfidence and debt maturity structure of firms. China Finance Review International, 1(3), 262-279. https://doi.org/10.1108/20441391111144112

Widhiastuti, R., Kiswanto, K., \& Jati, K. W. (2020). The role of women's leadership in manufacturing companies listed on the Indonesia Stock Exchange. The Indonesian Journal of Accounting Research, 23(1), 49-66. https://doi.org/10.33312/ijar.461

Zeng, S., \& Wang, L. (2015). CEO gender and corporate cash holdings: Are female CEOs more conservative? Asia-Pacific Journal of Accounting \& Economics, 22(4), 449-474. https://doi.org/10.1080/16081625.2014.1003568 
The Indonesian Journal of Accounting Research - May, Vol. 24, No.2 , 2021

intentionally blank 